\title{
CHEMISTRY IN IRELAND
}

\author{
By Prof. John Read, F.R.S.
}

\begin{abstract}
$\mathrm{A}^{\mathrm{N}}$ $\mathrm{N}$ interesting booklet has recently been published which shows us that, despite great handicaps several branches of science were cultivated in Ireland during the seventeenth, eighteenth and nineteenth centuries*. Among them, chemistry was closely linked with medicine, whether studied in institutions or less formally in hedge-schools or as a hereditary interest. Thus, the illustrious Robert Boyle entered chemistry through medicine; and it was during his lifetime that the institutional development of chemistry in Ireland began with the foundation in 1683 of the Dublin Philosophical Society. Richard Kirwan, when he left Ireland for France in the middle of the following century, had received his early education, including a good grounding in chemistry, from a well-known master of a hedge-school at Ballyragget, named Patsull. A century later, Cornelius O'Sullivan-" "the founder of the modern science of biochemistry"-won a scholarship from his humble school in Bandon which paved the way for him to study chemistry under A. W. Hofmann in London, and later to specialize in the chemistry of brewing. These are three Irish chemists who rose to eminence at different periods and became fellows of the Royal Society; and there are many others of note in the list of sixty-three names forming the index to the booklet now under notice.
\end{abstract}

Unlike England and Scotland, Ireland had few links with alchemy or early chemistry. Perhaps the earliest connexion may be discerned in the preparation of a distilled spirit called usquebaugh ('water of life'), which gave its name to the later 'whisky' and is said to have been made and appreciated in Ireland so far back as 1100. Even during 1652-53 Robert Boyle found his native land so disturbed that it was "hard to have any Hermetic thoughts in it;" and except for the charlatan, William Butler, the only reputed alchemist in the list we are considering is Peter Woulfe, who invented 'Woulfe's bottle', discovered picric acid, and gained the Oepley Medal of the Royal Society in 1768 - so that he was not much of an alchemist after all.

Boyle and Woulfe were born in Treland but prosecuted most of their chemical work elsewhere, and a similar statement applies to many other chemists in the list. Thus, Bryan Higgins, who is said to have almost forestalled the Leblanc soda process, opened a school of practical chemistry in Greek Street, Soho, in which he conducted research work during 1774-96; William James MacNeven, sometimes called the 'father of American chemistry', held the chairs of chemistry and materia medica during 1812-20 in the Now York College of Physicians and Surgeons ; and James Muspratt, born in Dublin in 1793; became the founder of the alkali industry in England. Muspratt's soda, made at Liverpool by the Leblane process, was originally given away "so as to prejudice people in its favour", whereupon the demand rose to such heights that new works were erected at St. Helens in 1828. One of his four sons, James Sheridan

* Three Centuries of Irish Chemists. Edited by Deasmumhan ó Raghallaigh. Pp. 30+4 plates. (Cork University Press, 1941.) 28, 6d.
Muspratt, discovered, in collaboration with Hofmann, $p$-toluidine and $m$-nitraniline, and achieved further fame through his celebrated dictionary of "Chemistry as Applied and Relating to the Arts and Manufactures", published in 1860 , to the editing of which Michael Murphy (from Co. Clare) "devoted sixteen hours a day for two years".

Of those chemists who went to Ireland from outside and rendered service to Irish chemistry, Sir Humphry Davy was a veritable bird of passage: in 1810 he gave six popular lectures on electro-chemistry before the Royal Dublin Society for a fee of five hundred guineas, and followed this up in 1811 by six more lectures on agricultural chemistry for which he received seven hundred and fifty pounds. In 1813, Edmund Davy, encouraged perhaps by his cousin's account of Ireland as a sphere of operations for chemists, took up the professorship of chemistry at the Royal Cork Institute, an appointment which he held until 1826, when he succeeded William Higgins in the chair of chemistry of the Royal Dublin Society ; it was ten years later that he discovered acetylene.

Chemistry in Ireland in the second half of the nineteenth century owed much to the Royal College of Chemistry, opened in London in 1845 with A. W. Hofmann as the first professor. Of Hofmann's original staff and students, Thomas Rowney, Robert Galloway, John Blyth and Edmund Rolands were all in the course of time appointed to chairs of chemistry in Ireland. In later days such men as Alfred Senier, Sir W. N. Hartley, and Sir G. T. Morgan went to Ireland and made valuable contributions to the development of chemistry in that country.

There is an impressive roll of native Irish chemists who carried out their work mainly in Ireland. Among these may be found, at about the end of the eighteenth century : David MacBride, a contemporary of Joseph Black (himself a son of Belfast parents); Richard Kirwan, author of the well-known "Essay on Phlogiston" (1787) ; and William Higgins, nephew of Bryan Higgins and occupant of "a place of honour in the development of the atomic theory". Sir Robert Kane, a distinguished figure in Irish scientific and academic circles, is known in chemistry for his preparation of mesitylene from acetone and as the author of a popular text-book entitled "Elements of Chemistry", first published in 1841-43. Maxwell Simpson, professor of chemistry in Queen's College, Cork, during 1872-91, studied under Kolbe and Bunsen, and afterwards worked with Wurtz, in Paris. He "takes his place among the great chemists who laid the foundations of organic chemistry in the nineteenth century". Last in chronological order, but one of the first in chemical genius, comes Hugh Ryan, who worked with Emil Fischer in his classical researches on sugars, and held the chair of chemistry in University College, Dublin, from 1908 until 1931. His death in that year, at the age of fifty-eight, was a severe loss to Irish chemistry, for it is said with truth that Ryan "was undoubtedly the leading organie chemist in Ireland in his day". 